\title{
Review
}

\section{Role of neural precursor cells in promoting repair following stroke}

\author{
Pooya DIBAJNIA ${ }^{1}$, Cindi M MORSHEAD ${ }^{1,2}$ \\ ${ }^{1}$ Department of Surgery, Division of Anatomy, University of Toronto, Toronto, ON M5S 3E1, Canada; ${ }^{2}$ Institute of Medical Science, \\ University of Toronto, Toronto, ON, Canada M5S 1 A8
}

\begin{abstract}
Stem cell-based therapies for the treatment of stroke have received considerable attention. Two broad approaches to stem cell-based therapies have been taken: the transplantation of exogenous stem cells, and the activation of endogenous neural stem and progenitor cells (together termed neural precursors). Studies examining the transplantation of exogenous cells have demonstrated that neural stem and progenitor cells lead to the most clinically promising results. Endogenous activation of neural precursors has also been explored based on the fact that resident precursor cells have the inherent capacity to proliferate, migrate and differentiate into mature neurons in the uninjured adult brain. Studies have revealed that these neural precursor cell behaviours can be activated following stroke, whereby neural precursors will expand in number, migrate to the infarct site and differentiate into neurons. However, this innate response is insufficient to lead to functional recovery, making it necessary to enhance the activation of endogenous precursors to promote tissue repair and functional recovery. Herein we will discuss the current state of the stem cell-based approaches with a focus on endogenous repair to treat the stroke injured brain.
\end{abstract}

Keywords: neural precursor cells; stem cells; stroke; growth factors; neurogenesis; angiogenesis; transplantation; migration; adults

Acta Pharmacologica Sinica (2013) 34: 78-90; doi: 10.1038/aps.2012.107; published online 8 Oct 2012

\section{Introduction}

Stroke is one of the leading causes of long-term disability and death in the world. Currently, the only treatment for stroke is thrombolytic tissue plasminogen activator (t-PA), which has been shown to reduce ischemic damage and permanent disability if administered within 3-4.5 h after onset ${ }^{[1,2]}$. However, the short effective time window, as well as the potential for a variety of complications, means that only $3 \%-5 \%$ of stroke patients receive t-PA treatment. A long-term treatment is needed to repair infarct damage and improve functional recovery in stroke patients.

Stroke results in the necrosis of brain tissue, leading to the loss of the intricate arrangement of neurons, glial cells, and vasculature. Neural stem cells in the adult brain hold great promise for the development of neural repair strategies. Specifically, neural stem and progenitor cells - collectively known as neural precursor cells (NPCs) - possess the ability to generate the neural cell types present in the brain. The use of NPCs in cell-based therapy has focused on two distinct approaches: endogenous and exogenous cell-based strategies.

\footnotetext{
* To whom correspondence should be addressed.

E-mail cindi.morshead@utoronto.ca

Received 2012-05-04 Accepted 2012-07-02
}

The exogenous approach involves the propagation of NPCs in vitro and their subsequent transplantation to achieve regeneration and recovery. In the endogenous approach, NPCs resident in the brain are induced to proliferate, migrate to the infarct site, differentiate into various neural cells needed for repair, and functionally integrate into the tissue to promote recovery. This review aims to provide an understanding of NPCs, and to present current findings in the two approaches of cellbased therapy for ischemic stroke, with a focus on endogenous repair strategies.

\section{Neural precursor cells}

By definition, a stem cell has the capacity to self-renew indefinitely and the ability to give rise to cells that generate differentiated progeny. A neural stem cell generates multipotent progeny which can differentiate into neurons, astrocytes, and oligodendrocytes. A neural progenitor cell possesses limited self-renewal capacity and differentiation potential ${ }^{[3]}$. Neural stem and progenitor cells are collectively referred to as NPCs.

Historically, NPCs were thought to exist only in the developing brain, while the adult mammalian brain was presumed post-mitotic and devoid of regenerative capacity. However, seminal works by Reynolds and Weiss showed the presence of NPCs in the adult mammalian central nervous system 
$(\mathrm{CNS})^{[4,5]}$. These studies used a colony forming assay which involved the dissection and plating of mouse CNS cells, including the periventricular region lining the forebrain lateral ventricles. Cells were cultured in the presence of epidermal growth factor (EGF) and after $7 \mathrm{~d}$ in vitro, clonally derived free floating colonies (termed neurospheres) were observed. Individual neurospheres could be dissociated, replated in EGF, and passaged indefinitely thereby revealing the stem cell property of self-renewal. The cells were also shown to differentiate into the three CNS cell-types, confirming their multipotentiality. The discovery of NPCs in the adult brain offered new hope for the possibility of regeneration in the adult brain.

Adult NPCs are found in two discrete regions: the subventricular zone $(S V Z)^{[6]}$, and the dentate gyrus (DG) of the hippocampus ${ }^{[7]}$. The SVZ is a region lining the walls of the forebrain lateral ventricles, and consists of the ependymal and subependymal layers. The NPCs are found in the subependyma, adjacent to the single-cell ependymal layer lining the ventricle $\mathrm{e}^{[6,8,9]}$. Neural stem cells in the SVZ are slowly proliferating cells ${ }^{[6]}$ that express glial fibrillary acidic protein $(\text { GFAP })^{[10,11]}$ and are referred to as type- $B$ cells ${ }^{[12]}$. Type-B cells give rise to rapidly dividing progenitor cells called type- $C$ cells, which subsequently give rise to neuroblasts (type- $A$ cells) ${ }^{[12]}$. In rodents, type-A cells migrate through the rostral migratory stream (RMS) to the olfactory bulb, where they differentiate into interneurons and become functionally integrated into the neuronal network ${ }^{[13,14]}$. Neurogenesis in the rodent olfactory bulb has been suggested to play a role in olfactory learning and memory ${ }^{[15]}$. In humans, samples from the SVZ of adult brains have shown the presence of $\mathrm{GFAP}^{+}$cells capable of forming self-renewing, multipotent neuropheres in vitro, confirming the presence of NPCs in the adult human brain ${ }^{[16,17]}$. Furthermore, neuroblasts migrating from the SVZ to the olfactory bulb, analogous to the rodent RMS, have been observed in humans ${ }^{[18]}$, albeit in much smaller numbers than what is observed in rodents ${ }^{[19]}$.

NPCs that express GFAP are also found in the subgranular zone of the DG, between the hippocampal hilus and granular layer $^{[7,20-22]}$. These NPCs proliferate, migrate into the granular layer, and extend processes that functionally integrate into the overlying molecular layer ${ }^{[23,24]}$. Unlike the SVZ, however, NPCs from the DG show limited self-renewal and multipotent capacities when propagated in vitro, and there is controversy as to whether the DG contains "true" stem cells ${ }^{[25,26]}$. In humans, post-mortem analysis of hippocampi has revealed the presence of neurons derived from proliferating cells in patients injected with the proliferation marker bromodeoxyuridine ${ }^{[27]}$. NPCs in the live adult hippocampus have also been identified using proton magnetic resonance spectroscopy ${ }^{[28]}$. Given the critical role of the hippocampus in learning and memory, the NPCs in this region are considered an important target for treating the stroke injured brain ${ }^{[29]}$.

\section{Stroke models and outcome measures}

Given the clinical prevalence of ischemic over hemorrhagic stroke, most research has focused on rat and mouse models of ischemic stroke. Early stroke studies used the common carotid artery occlusion model, which induced global ischemia ${ }^{[30]}$. From a clinical perspective, ischemic stroke is more focal, commonly affecting the striatum and internal capsule. Accordingly, a majority of recent studies use the middle cerebral artery occlusion (MCAO) model as it induces focal ischemic damage to the striatum and overlying cortex. Variations in the location (proximal, distal) and duration of MCAO (transient, permanent) can be used to induce different extents of damage in distinct regions throughout the brain (reviewed by Lindvall and Kokaia ${ }^{[31,32]}$.

Other models are used to address the clinical heterogeneity of ischemic stroke. For instance, lesions restricted to the cortex have been modelled using a variety of techniques such as photothrombic ischemia ${ }^{[33,34]}$, devascularisation ${ }^{[35]}$, and cortical aspiration ${ }^{[35]}$. Endothelin-1, a potent vasoconstrictor that results in transient ischemia followed by reperfusion of the tissue, has also been used to induce stroke ${ }^{[36]}$.

A variety of outcome measures are used to determine the efficacy of the treatments employed. In cell-based therapies a comprehensive analysis of the cell phenotypes is performed using specific cell markers. In addition, infarct volume, as well as neuroimaging techniques including MRI and CT, have been used to examine the effects of treatments on angiogenesis and tissue repair. Arguably, the most clinically relevant outcome measure is functional recovery. As such, the degree of sensorimotor recovery, as determined by a number of behavioural assays, is commonly used to determine efficacy of the treatment employed (summarized in Table 1). In this review we will consider some of the parameters important for developing and employing NPC based strategies with a focus on the endogenous approach for ischemic stroke repair.

\section{Exogenous approach: transplanting neural precursor cells following stroke}

A variety of stem cell types have been used for decades in cell transplantation studies to treat stroke, and while some have shown promise, the success of this treatment strategy is yet to be realized. Initial pioneering work using fetal brain cells in ischemic rat models provided some evidence of synaptic integration and cognitive recovery, although the limited supply, difficulty ensuring the purity of the cell source and the ethical issues surrounding the cell type have largely impeded the progress of these studies ${ }^{[37,38]}$. Clinical trials using human NT2 teratocarcinoma cells and fetal porcine neural cells were met with risks of adverse effects and limited improvement ${ }^{[39,40]}$. More promising was the use of autologous bone marrow mononuclear cells (BMMCs) and mesenchymal stem cells (MSCs), which are now in Phase II clinical trials as the treatments were shown to be safe and further demonstrated some neurological improvements ${ }^{[41,42]}$. More recently, induced pluripotent stem cells (iPSCs) have gained attention due to their non-embryonic origin and their potential to be induced to a neural lineage. Despite the exciting prospects of these cells, considerable safety concerns remain regarding their potential to form teratomas. (For a more detailed review of 
Table 1. Summary of the effects of the activation factors on endogenous repair processes in stroke models.

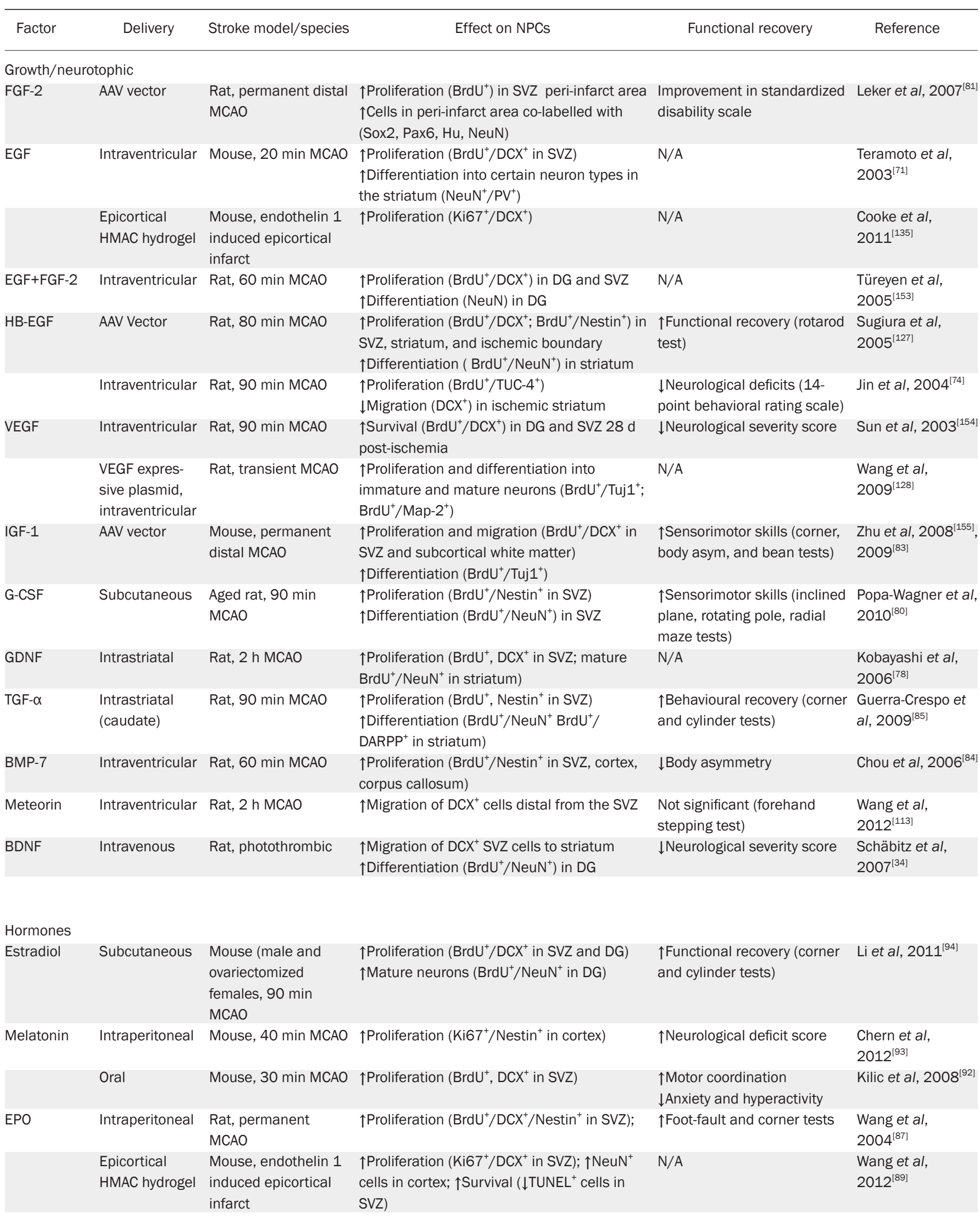




\begin{tabular}{|c|c|c|c|c|c|}
\hline Factor & Delivery & Stroke model/species & Effect on NPCs & Functional recovery & Reference \\
\hline $\mathrm{EPO}+\mathrm{G}-\mathrm{CSF}$ & Subcutaneous & Rat, 90 min MCAO & $\begin{array}{l}\uparrow \text { Proliferation and migration }\left(\mathrm{Ki} 67^{+} / \mathrm{Nestin}^{+}\right. \\
\text {in SVZ and peri-infarct region) } \\
\uparrow \text { Differentiation }\left(\mathrm{BrdU}^{+} / \mathrm{NeuN}^{+}\right)\end{array}$ & $\begin{array}{l}\uparrow \text { Sensorimotor skills (body } \\
\text { asymmetry, locomotor } \\
\text { activity, and grip strength) }\end{array}$ & Liu et al, 2010 $[156]$ \\
\hline $\mathrm{EPO}+\mathrm{EGF}$ & Intraventricular & $\begin{array}{l}\text { Rat, permanent } \\
\text { cortical devasculariz- } \\
\text { ation }\end{array}$ & $\begin{array}{l}\uparrow \text { Migrating cells from SVZ to infarct } \\
\uparrow \text { Differentiation }\left(\mathrm{BrdU}^{+} / \mathrm{NeuN}^{+}\right)\end{array}$ & $\begin{array}{l}\downarrow \text { Asymmetry and forelimb } \\
\text { inhibition } \\
\uparrow \text { Reaching success }\end{array}$ & Kolb et al, 2007 ${ }^{[72]}$ \\
\hline \multicolumn{6}{|l|}{ Others } \\
\hline $\begin{array}{l}\text { Notch } 1 \\
\text { receptor } \\
\text { activating } \\
\text { antibody }\end{array}$ & Intraventricular & Rat, 90 min MCAO & $\uparrow$ Proliferation (BrdU $/ \mathrm{DCX}^{+}$in SVZ); & N/A & $\begin{array}{l}\text { Wang et al, } \\
2009^{[108]}\end{array}$ \\
\hline $\begin{array}{l}\text { Notch ligand } \\
\text { DIl4 }\end{array}$ & Intraventricular & $\begin{array}{l}\text { Rat, permanent } \\
\text { MCAO }\end{array}$ & $\mathrm{N} / \mathrm{A}$ & $\downarrow$ Motor deficits & $\begin{array}{l}\text { Androutsellis- } \\
\text { Theotokis et al, } \\
2006^{[109]}\end{array}$ \\
\hline Pifithrin- $\alpha$ & $\begin{array}{l}\text { Intraventricular } \\
\text { +intraperitoneal }\end{array}$ & Rat, 90 min MCAO & $\begin{array}{l}\uparrow \text { Proliferation \& } \uparrow \text { Survival }\left(\uparrow \mathrm{BrdU}^{+} \downarrow \mathrm{TUNEL}^{+}\right. \\
\text {cells in SVZ) }\end{array}$ & $\uparrow$ Motor activity & Luo et al, 2009 ${ }^{[100]}$ \\
\hline SDF-1 & $\begin{array}{l}\text { Systemic } \\
\text { (osmotic pump) }\end{array}$ & $\begin{array}{l}\text { Mouse, permanent } \\
\text { MCAO }\end{array}$ & $\begin{array}{l}\uparrow \text { Migration of neuroblasts }\left(\mathrm{DCX}^{+}\right) \text {to peri- } \\
\text { infarct area }\end{array}$ & $\begin{array}{l}\downarrow \text { Motor deficit (forelimb } \\
\text { extension test) }\end{array}$ & $\begin{array}{l}\text { Ohab et al, } \\
2006^{[110]}\end{array}$ \\
\hline Ang-1 & $\begin{array}{l}\text { Systemic } \\
\text { (osmotic pump) }\end{array}$ & $\begin{array}{l}\text { Mouse, permanent } \\
\text { MCAO }\end{array}$ & $\begin{array}{l}\uparrow \text { Migration of neuroblasts }\left(\mathrm{DCX}^{+}\right) \text {to peri- } \\
\text { infarct area }\end{array}$ & $\begin{array}{l}\downarrow \text { Motor deficit (forelimb } \\
\text { extension test) }\end{array}$ & $\begin{array}{l}\text { Ohab et al, } \\
2006^{[110]}\end{array}$ \\
\hline $\begin{array}{l}\text { Cyclosporin } \\
\text { A }\end{array}$ & $\begin{array}{l}\text { Intraperitoneal+ } \\
\text { systemic osmotic } \\
\text { minipump }\end{array}$ & $\begin{array}{l}\text { Mouse, cortical } \\
\text { c devascularization }\end{array}$ & $\begin{array}{l}\uparrow \mathrm{BrdU}^{+} / \mathrm{GFAP}^{+} \text {cells in regenerated cortical } \\
\text { tissue; capable of forming self-replicating/ } \\
\text { multipotent neurospheres }\end{array}$ & $\begin{array}{l}\downarrow \text { Foot-fault test } \\
\text { (improvement) }\end{array}$ & $\begin{array}{l}\text { Erlandsson et al, } \\
2011^{[104]}\end{array}$ \\
\hline $\begin{array}{l}\text { Retinoic acid } \\
\text { +enriched } \\
\text { envir }\end{array}$ & Retinoic acid diet & t Rat, 90 min MCAO & $\uparrow \mathrm{BrdU}^{+} / \mathrm{DCX}^{+}$cells in SVZ and striatum & Not significant & $\begin{array}{l}\text { Plane et al, } \\
2008^{[157]}\end{array}$ \\
\hline
\end{tabular}

different stem cells, see Burns and Steinberg $\left.{ }^{[43]}\right)$.

Transplantation of NPCs has advantages over other cell types for a number of reasons. For example, their neural restricted lineage limits the potential for producing undesired non-neural phenotypes while permitting the production of CNS cells. Further, the fact that NPCs reside in a very well defined region of the adult brain raises the possibility of autologous transplantation, although the extraction of endogenous NPCs remains an issue. Indeed, the difficulties associated with accessing the NPCs in the adult brain have driven pre-clinical studies to employ NPCs derived from other stem cell types. Fetal and embryonic stem cell-derived NPCs, after intracranial transplantation, migrate towards site of ischemia, differentiate into neurons, and survive for up 12 weeks ${ }^{[4-46]}$. Behavioural improvements have been shown in forelimb tasks in rats, and this has coincided with improved electrophysiological cell recordings in the appropriate anatomical sites in the brain ${ }^{[46,47]}$. These promising results have led to an ongoing Phase I clinical trial of intracranial transplantation of embryonic stem cellderived neural stem cells in patients with subcortical/basal ganglia stroke ${ }^{[48]}$. More recently, iPSC-derived NPCs have also been shown to produce mature neurons, though no functional assessments were examined ${ }^{[4]}$. Studies that employed adult NPCs isolated from the SVZ and expanded in neurospheres have also shown NPC survival and differentiation after transplantation, although their survival is lower than NPCs derived from embryonic neural precursors ${ }^{[50-52]}$.

There are a number of questions that remain outside of the cell source to be employed. For instance, the route of administration and the time to transplant post-stroke must also be examined. While the previously mentioned studies used intracranial administration, there has also been increasing interest in intravascular delivery of NPCs. Reports indicate that NPCs can "home" into sites of ischemic injury, reduce infarct volume and lead to behavioural improvements ${ }^{[53-55]}$. The NPCs were shown to have immunomodulatory and antiapoptotic effects ${ }^{[54]}$. A recent meta-analysis examined the effect of intravenous delivery of NPCs in 60 preclinical studies for neurological diseases, and summarized the overall outcomes into morphological, behavioural, and molecular effects $^{[56]}$. The study showed that NPCs have a greater effect on behavioural outcomes than MSCs, BMMCs, and other stem cell types ${ }^{[56]}$, which suggests that intravascular delivery of NPCs may be a clinically viable therapy.

Successful application of exogenous NPCs in the clinic requires the optimization of various parameters including the time of transplantation and dosage. Indeed, the survival of transplanted cells is dependent on changes in the brain 
environment after ischemia. There is no current consensus on the most effective time of delivery. The meta-analysis by Janowski et al found no significant difference in behavioural, molecular, or morphological outcomes in relation to timing of cell delivery ${ }^{[56]}$. The meta-analysis, however, found a significant positive correlation between cell dose (up to $10^{7}$ cells) and improved molecular outcomes. Hence, the cell type, dosage, and time of delivery and administration route need to be considered when developing exogenous strategies for human use.

\section{The endogenous approach: activating neural precursor cells to promote self-repair}

NPCs in the adult brain demonstrate the fundamental properties in vivo that would be necessary for developing strategies to promote their contribution to neural repair: proliferation, migration, and differentiation into neural phenotypes. In the first demonstration of the recruitment of NPCs in stroke repair, transient ischemia was induced in rats by MCAO, and immunohistochemistry demonstrated SVZ-derived NPC proliferation, migration to the site of infarct, and the generation of neurons in the striatum as well as the parietal lobe ${ }^{[57,58]}$. Further studies suggested that this activation and recruitment process persists for several months after the ischemic attack ${ }^{[59,60]}$, and that newly formed neurons become synaptically integrated as determined by morphological and electrophysiological studies ${ }^{[60,61]}$. These phenomena have more recently been examined in humans, where post-mortem biopsies of stroke patients have shown the presence of proliferating and differentiating cells in the ischemic penumbra as well as the ipsilateral $S V Z^{[62,63]}$. However, this endogenous activation is clearly not sufficient for functional recovery as demonstrated by the persistent and devastating functional impairments observed in patients following stroke.

Notably, NPCs in the DG have also been shown to proliferate and differentiate into mature neurons after ischemia ${ }^{[30,64]}$. However, no conclusive evidence to date has shown the migration of NPCs out of the DG into other brain regions ${ }^{[65]}$. As a result, the regenerative capacity of NPCs in the DG are restricted to the hippocampus, and much of the research has focused on the more migratory NPCs observed in the SVZ.

Developing endogenous activation strategies to promote tissue repair and functional recovery relies on the ability to stimulate endogenous precursors in the brain using a variety of exogenous "activation factors", including growth factors and cytokines. The premise of the endogenous repair strategy is to take advantage of the inherent properties of NPCs to proliferate (and permit an expansion of the NPC pool), migrate to the site of the injury and differentiate into mature cells in the injured brain. Similar to the challenges faced with exogenous transplant therapies, there are many unanswered questions such as which types of mature cells - glial and/or neuronal - need to be replaced in the stroke injured tissue in order to facilitate recovery. Understanding the mechanisms that promote regeneration and recovery will ultimately underlie the choice of NPC activation factors. Activation factors may mediate their effects by: modifying cell proliferation kinetics, promoting cell survival, enhancing cell migration to infarct site and/or promoting neurogenesis, and angiogenesis. Table 1 provides a summary of recent research on various activation factors. Herein we discuss how the above processes are enhanced by activation factors, with functional improvement as the end-goal.

\section{Proliferation}

Proliferation represents the first step of the adult NPCs' response to ischemia. Indeed, the injury alone is sufficient to enhance the NPC proliferation and thereby increase the size of the NPC pool ${ }^{[66,67]}$. Given the fact that NPCs make up a very small fraction of cells in the adult brain (less than $0.5 \%$ of the cells in the SVZ are stem cells ${ }^{[6,68]}$, and the progeny comprise approximately $15 \%{ }^{[69]}$ ), increasing the size of the NPC pool is an important factor in endogenous repair strategies. Moreover, some factors that promote NPC expansion have also lead to increased olfactory bulb neurogenesis in non-injured animals, or in the stroke lesion site of injured animals. For example, intraventricular administration of EGF has been shown to promote NPC proliferation in the SVZ of uninjured and stroke injured animals ${ }^{[70,71]}$, and NPCs in injured brains subsequently migrated to the lesion site where they developed into mature neurons ${ }^{[71,72]}$. Adult NPCs express the EGF receptor (EGFR), and increase their sensitivity to EGF and other EGFR ligands in response to ischemia by upregulating EGFR expression ${ }^{[73]}$. Indeed, heparin-binding EGF-like growth factor (HB-EGF), an EGFR ligand, delivered intraventricularly one day after ischemia in rats increased proliferation of NPCs in the SVZ and DG, and improved neurological deficits compared to salineadministered post-ischemic rats ${ }^{[74]}$.

A plethora of other growth and trophic factors have been shown to increase NPC proliferation: vascular endothelial growth factor (VEGF) ${ }^{[75-77]}$, glial cell-line derived neurotrophic factor $(\mathrm{GDNF})^{[78]}$, granulocyte colony stimulating factor $(\mathrm{G}-\mathrm{CSF})^{[79,80]}$, basic fibroblast growth factor $(\mathrm{FGF}-2)^{[81]}$, insulinlike growth factor $(\mathrm{IGF}-1)^{[82,83]}$, bone morphogenic protein 7 (BMP-7) ${ }^{[84]}$, transforming growth factor a (TGF-a) ${ }^{[85]}$, and brain derived neurotrophic factor (BDNF) ${ }^{[33]}$. While many of these factors have been shown to act directly through their associated receptors, it is also possible that they mediate their proliferative effects indirectly via immunomodulation, neuroprotection, and angiogenesis. A summary of these factors are found in Table 1.

From a clinical perspective, enhancement of NPC proliferation increases the risk of aberrant cell growth and tumour formation, especially since some growth factors are well-known mitogens. Using certain hormones to stimulate NPCs may be a safer approach, as their physiological levels fluctuate dramatically with minimal tumorigenic effects. One molecule of interest is erythropoietin (EPO) which acts directly upon EPO receptors present on NPCs to stimulate their proliferation ${ }^{[86,87]}$. Intraperitoneal administration of EPO in rats after unilateral carotid artery occlusion led to an improvement in sensorimotor outcomes $14 \mathrm{~d}$ after ischemia compared to saline-injected stroke-injured rats ${ }^{[88]}$. In agreement with a more recent 
study by Wang et al, the studies have shown a decreased number of apoptotic nuclei ipsilateral to the infarct, suggesting an additional role for EPO in extending cell survival ${ }^{[88,}$ ${ }^{89]}$. Growth hormone $(\mathrm{GH})$ has also been shown in vitro to increase proliferation of neurosphere-derived NPCs by acting directly through the $\mathrm{GH}$ receptor ${ }^{[90,91]}$. In uninjured mice, GH increased NPC proliferation in the SVZ and olfactory bulb when delivered intraventricularly. However, there is no evidence to date on the effects of GH on NPCs in an animal stoke model, which may be a novel therapeutic target. Some recent work has demonstrated that melatonin can also promote NPC proliferation and reduce neurological deficits that result following stroke ${ }^{[92,93]}$. Melatonin, delivered orally to mice for $29 \mathrm{~d}$ after MCAO, leads to improved motor coordination, as well as decreased hyperactivity and anxiety ${ }^{[92]}$. In a recent study, estradiol was delivered subcutaneously in male and ovarectomized female mice and was shown to enhance NPC proliferation post-ischemia in the SVZ and DG, and to increase neurogenesis in the DG (but not in the SVZ) ${ }^{[94]}$. While the study provided some evidence that this enhanced proliferation and neurogenesis can result in functional recovery, the deleterious role of estradiol in some human cancers is welldocumented, and therefore the use of this hormone in a clinical setting demands further study.

\section{Promoting survival}

Proliferation of NPCs can occur by shortening the cell cycle, and supporting this process may increase the risk of tumorigenesis. An alternative approach to expanding the NPC pool post-ischemia is by promoting cell survival through inhibition of apoptosis. Within the adult NPC population, $60 \%$ of the newborn progeny undergo cell death under baseline conditions $^{[68]}$, hence sparing the NPCs from cell death would effectively increase the size of the NPC pool. The PI3K-Akt pathway has been shown to be important in NPC survival in the developing brain through the upregulation of anti-apoptotic genes ${ }^{[95,96]}$. Administration of G-CSF to cultured neurons and neuroblastoma cells led to strong activation of the PI3KAkt pathway resulting in decreased caspase $3 / 7$ activity and decreased apoptosis ${ }^{[79]}$. G-CSF receptors were found to be expressed on cultured adult NPCs, and intravenous administration of G-CSF in stroke-injured rats promoted NPC survival in vivo, suggesting a possible anti-apoptotic role for G-CSF on NPCs following ischemia ${ }^{[79]}$. In addition, the anti-apoptotic effect of G-CSF was shown to be mediated by the STAT3 pathway in ischemic rats ${ }^{[97]}$. Other factors, such as IGF-1, activate the PI3K-Akt pathway and inhibit apoptosis by the phosphorylation of glycogen synthase kinase $3 \beta$, thereby promoting cell survival $^{[98]}$.

Other potential targets to promote cell survival include the tumour suppressor p53, which is known to negatively regulate proliferation and increase apoptosis in NPCs ${ }^{[99]}$. Pifithrin-a, a p53 inhibitor, has been shown to enhance NPC proliferation and survival in the SVZ when administered intraventricularly for $6 \mathrm{~d}$ post MCAO ischemia, and further, functional improvements were observed using a standardized motor disability scale ${ }^{[100,101]}$. Inhibition of p53 promotes survival through downregulation of p53-upregulated modulator of apoptosis (PUMA $)^{[100,102]}$. More recently it was found that cyclosporine A (CsA), a commonly used immunosuppressive drug, acts directly on NPCs to increase their survival without affecting cell cycle kinetics ${ }^{[103]}$. While the pro-survival mechanism has not been fully elucidated, the administration of CsA in vivo resulted in $>2$ fold increase in the size of the NPC pool in control mice. Moreover, mice that received CsA following stroke showed an expansion of the NPC pool, migration of the NPCs to the site of injury, new tissue formation at the site of cortical ischemia, as well as recovery of motor function ${ }^{[104]}$. Hence, a number of pro-survival pathways have demonstrated efficacy in models of stroke.

Other possible mechanisms to increase the size of the NPC pool include activation of signaling pathways that promote a change in the mode of division of NPCs. For example, a change in the mode of division of stem cells from asymmetric division (producing one stem cell and one progenitor cells) to symmetric (producing two stem cell progeny) could effectively double the size of the stem cell pool with each division. One factor recently identified as a regulator of symmetric divisions in adult neural stem cells is Wnt signalling ${ }^{[105]}$. Active Wnt signaling was found to be necessary for regeneration of the SVZ following ablation of the NPCs in vivo. Indeed, in the absence of Wnt signaling no repopulation of the neural stem cell pool occurs as the stem cells do not undergo symmetric division. Instead, the asymmetric cell divisions result in maintenance of the stem cell pool but not expansion. Piccin and Morshead also demonstrated that Wnt signaling is upregulated in NPCs in the SVZ following stroke, suggesting that this pathway plays a role in the normal expansion of NPCs observed following stroke alone.

Notch signalling has also been implicated in the maintenance and expansion of NPC pool in the adult brain (reviewed by Ables et al $\left.{ }^{[106]}\right)$. The transmembrane Notch receptor and its downstream targets are expressed on NPCs in the SVZ, while the Notch ligands - Jagged1 and Delta1 - are expressed by astrocytic $\mathrm{GFAP}^{+}$cells $^{[107,108]}$. The interaction between the two cell types has been suggested to play a role in regulating the proliferation of NPCs in the SVZ ${ }^{[108]}$. In a rat MCAO model, a transient increase in the expression of Notch signalling molecules are seen up to $24 \mathrm{~h}$ post-ischemia ${ }^{[108]}$. In vitro administration of Notch ligands and inhibitors modulate NPC proliferation and differentiation in post-ischemic NPCs ${ }^{[107,109]}$. Intraventricular injection of Notch activators in vivo lead to increased cell proliferation in the SVZ for up to $24 \mathrm{~h}^{[108]}$, and has been shown to improve motor deficits in mice over a $45 \mathrm{~d}$ period $^{[108,109]}$. Thus various signalling pathways contribute post-ischemia to the expansion of the NPC pool through the inhibition of apoptosis, change in the cell cycle kinetics, mode of cell division, and regulation of proliferation.

\section{Migration}

In order for endogenous NPCs to contribute to recovery, it is necessary for NPCs to migrate from the SVZ through the 
brain parenchyma into the peri-infarct region and further, which must occur in sufficient numbers in order to generate sufficient numbers of cells. The increased migration to the peri-infarct region has been suggested to occur at the expense of migration to the olfactory bulb, the default path of NPC migration $^{[110]}$. A number of studies have looked at the receptor-ligand signalling pathways that are involved in the modest NPC migration that occurs post-stroke. Some of the factors involved include: stromal cell-derived factor 1 (SDF-1; also called CXCL12) and CXC chemokine receptor 4 (CXCR4) ${ }^{[58,110]}$; angiopoietin-1 (Ang1) and Tie-2 ${ }^{[110]}$; monocyte chemoattractant protein-1 (MCP-1; also called CCL2) and CC chemokine receptor $2(\mathrm{CCR} 2)^{[111]}$; osteopontin and integrin $\beta_{1}{ }^{[112]}$; and, meteorin $^{[113]}$. With the goal of enhancing migration, controlled delivery of ligands has been examined in vivo. In vitro, SDF-1 has been shown to promote NPC migration by activating the ERK $1 / 2$ pathway, and treatment of NPCs with an ERK $1 / 2$ pathway inhibitor abolished the stimulatory effect of SDF-1 on migration $^{[114]}$. Intraventricular administration of SDF-1 in ischemic mice increases the number of doublecortin-expressing neuroblasts that migrate to the peri-infarct region $7 \mathrm{~d}$ poststroke $^{[110]}$. CXCR4 antagonists suppress the migration of neuroblasts into the peri-infarct region ${ }^{[58]}$, causing neuroblasts to migrate non-directionally and disperse diffusely throughout the cortex following stroke ${ }^{[110]}$. A similar effect on cell migration is observed with Ang1/Tie-2 signalling modulation by administering Ang1 and Tie-2 antagonist intraventricularly ${ }^{[110]}$. Finally, both in vitro ${ }^{[115]}$ and transplantation ${ }^{[111]}$ studies using NPCs have shown that MCP-1/CCR2 signalling promotes the directed migration of NPCs towards the infarct region. Notably, MCP-1/CCR2 $2^{[116,117]}$, and SDF1/CXCR4 $4^{[118]}$ are also involved in the chemotaxis of inflammatory cells, hence these molecules may lead to a more pronounced immune response and may subsequently counteract neurogenic recovery.

Matrix metalloproteinases (MMPs) have also been implicated in neuroblast migration from the SVZ. MMPs are capable of degrading extracellular matrix proteins, involved in the cleavage of cell surface receptors, and are thought to play a role in many cell behaviours including proliferation, migration, differentiation and apoptosis ${ }^{[119]}$. In the adult brain, MMP-3 and -9 have been shown to be expressed by NPCs, and inhibition of MMPs in in vitro siRNA experiments, as well as MMP inhibitors in a mouse model, have revealed a reduction in NPC migration following MCAO ischemia ${ }^{[120,121]}$. The working hypothesis is that MMPs released by the NPCs digest the ECM to clear the path for neuroblast migration ${ }^{[122]}$. Considering that MMPs are also expressed by endothelial cells and astrocytes ${ }^{[123,124]}$ and in light of the increased gliosis that occurs following stroke, these cells may also be contributing to the enhanced migration of NPCs following stroke.

In thinking of ways to enhance and direct cell migration following injury, it is helpful to consider what is known about cell migration during development of the nervous system when all newborn cells are migrating to their final destination within the developing brain parenchyma. In recent studies, Babona-Pilipos et al, applied direct current electric fields to adult derived NPCs in vitro ${ }^{[125]}$, as it is well established that disruption of electric fields during development, or during wound healing, completely disrupts cell migration, leading to aberrant development and tissue repair ${ }^{[126]}$. When adult NPCs were exposed to a $250 \mathrm{mV} / \mathrm{mm}$ electric field, the NPCs undergo a rapid and directed migration towards the cathode $^{[125]}$. The migration could be entirely accounted for the application of the electric field and was not mediated by any chemotactic gradient that was established in the assay. These findings suggest that the application of electric fields may be a novel and clinically relevant approach to enhancing and directing the migration of NPCs to the site of injury and is worthy of further investigation.

\section{Differentiation and neurogenesis}

The importance of generating new neurons in cell-based therapies has not been completely established, and this is partly due to the fact that when NPCs do appear to differentiate into mature neurons, it is challenging to determine the extent to which these newborn neurons have synaptically and functionally integrated into the neural circuitry. Using markers for mature neurons, studies have shown several activations factors to facilitate differentiation: FGF-2 ${ }^{[81]}$, EGF ${ }^{[71]}, \mathrm{HB} \mathrm{EGF}^{[127]}$, VEGF $^{[128]}$, IGF-1 ${ }^{[83]}$, G-CSF $^{[80]}$, GDNF ${ }^{[78]}$, TGF- ${ }^{[85]}$, estradiol ${ }^{[94]}$, and $\mathrm{EPO}^{[89]}$ (Table 1). Indeed, it is possible that neurogenesis is not required for functional recovery. At least two studies have shown improvements in functional outcomes despite the lack of neurogenesis at the infarct site after activation factor administration. In the case of Erlandsson et al, CsA administration led to newly formed tissue at the site of the infarct that contained only newborn glial cells ${ }^{[104]}$. In Chern et al, intraperitoneal administration of melatonin after MCAO stroke in mice resulted in a reduction in neurological deficit, even though the increase in mature neurons was not significant ${ }^{[93]}$. These studies support the possibility that NPCs contribute to recovery through other mechanisms, such as providing factors that prevent secondary stroke damage, or by providing trophic support to existing cells in the infarct region ${ }^{[65,129]}$.

\section{Role of angiogenesis}

Angiogenesis plays an integral role in post-ischemic recovery, and is closely tied to neurogenesis ${ }^{[130]}$. Vasculature not only provides blood supply to the infarct region, but also stimulates NPCs by the endothelial secretion of various growth and chemotactic factors. VEGF and IGF-1 are released by endothelial cells in response to ischemia, and promote NPC proliferation and differentiation ${ }^{[82,83,131]}$. The receptor ligand interaction is also thought to act reciprocally, that is, signalling from NPCs promotes neovascularization, leading to the "coupling" of angiogenesis and neurogenesis ${ }^{[83,131]}$.

Vasculature can also provide a scaffold on which NPCs can migrate, observed by the close association of migrating NPCs and neuroblasts with vascular endothelial cells ${ }^{[110,132,133]}$. Selective inhibition of VEGFR2 attenuates post-ischemic NPC migration, supporting the role of VEGF in coupled angiogenesis and neurogenesis in stroke recovery ${ }^{[134]}$. Similarly, IGF- 
1, SDF-1/CXCR4, and Ang1/Tie-2 signalling from endothelial cells also facilitate the migration of NPCs along blood vessels $^{[83,110,132]}$. These studies provide strong support for the development of strategies that promote angiogenesis, which will ultimately lead to enhanced migration of NPCs and neurogenesis.

\section{Challenges}

One of the challenges to the application of NPC activation to the clinic is the delivery of activation factors. Some studies have used peripheral modes of administration (intravenous, subcutaneous, intraperitoneal), while others have attempted to target the brain directly. Peripheral administration minimizes trauma to the brain, but does not target NPCs directly and may lead to systemic effects that confound the activation factor's effect on NPCs. Alternatively, those that target the brain directly (intracerebral/intraventricular infusion of factors/viral vectors) may avoid systemic effects, but damage to the brain tissue and the increased risk of infection make them clinically impractical options. Recently, some bioengineering strategies have looked at a less invasive delivery of factors using an epicortically implanted hydrogel that releases factors in a spatially and temporally defined fashion ${ }^{[89,135]}$. The hydrogel technology delivers the factors of interest locally and resulted in greater brain tissue penetration than when the factors were delivered systemically or intraventricularly. This delivery strategy is a promising methodology for clinical application.

Another barrier to successful activation of endogenous NPCs is the difference in the neurogenic response between the young and aged brains. Many studies of activation factors use young adult rodents for stroke models. However, stroke occurs predominantly in the elderly in humans, and consequently studies need to take this into consideration in order for the results to be translational. While reports have confirmed that post-ischemic neurogenesis occurs in the aged brain, the response is significantly attenuated ${ }^{[136,137]}$. Furthermore, the response of NPCs to activation factors such as G-CSF and VEGF have been shown to be attenuated in aged mice $^{[80,138]}$, or absent with FGF-2 ${ }^{[139]}$. Gene expression analysis in the ischemic young and aged brains have shown that the aged brain upregulates the expression of genes related to DNA damage, cell cycle arrest, apoptosis, and inflammation, while genes related to axon and dentrite growth are downregulated $^{[140]}$. These global changes in gene expression may explain the differential response of the aged brain to ischemia.

As Table 1 summarizes, there are a plethora of activation factors that affect NPCs, and many others that may work through indirect mechanism. Successful translation of the endogenous approach to the clinic requires a thorough evaluation of the magnitude of the effect of individual and combinations of factors. Potential therapies need rigorous studies in multiple rodent models with different baseline conditions that are relevant to clinical conditions (hypertensive, diabetic, age, sex). Safety and efficacy testing in nonhuman primate (NHP) models are also recommended by STEPS II (Stem Cell
Therapies as an Emerging Paradigm in Stroke), given the anatomical differences, especially white matter, in gyrencephalic primate brains ${ }^{[141,142]}$. To date, little work has been done in primates, given the lack of an established NHP model for ischemic stroke, as well as the cost and limited availability of animals ${ }^{[141,143]}$. Ultimately, however, a transition to clinical trials is necessary to assess functional outcomes in humans, as animal models provide limited information about the recovery of functions such as speech, language, higher cognitive function, learning, and memory.

NPC proliferation and migration takes place after hemorrhagic stroke in rats ${ }^{[144]}$, and post-mortem analysis of human brains has suggested that increased neurogenesis occurs in patients with hemorrhagic stroke ${ }^{[145]}$. However, research has focused primarily on ischemic stroke models, and further research is necessary to determine whether the activation factors can enhance endogenous recovery in hemorrhagic models of stroke.

\section{Combinatorial aproaches to enhance stroke recovery}

An understanding of the mechanisms that underlie endogenous NPC activation will undoubtedly benefit transplantation strategies designed to promote stroke recovery. Indeed it has been hypothesized that NPCs in peri-infarct regions provide trophic support to existing cells to promote plasticity and/or prevent secondary damage ${ }^{[104]}$. If the latter mechanism has a greater contribution to stroke recovery, then combining endogenous and exogenous approaches may optimize the development of clinical therapies. Along these lines, transplanted NPC's may serve as vehicles for trophic factor delivery. This has been demonstrated in studies where transplanted NPCs expressing the BDNF gene lead to improved functional outcomes relative to control (nonexpressing) NPC recipients ${ }^{[146,147]}$. Transplantation of GDNFtransfected NPCs not only improves functional outcomes, but also increases BDNF expression, ultimately leading to improved cell survival ${ }^{[148]}$. Hypoxia-induction factor (HIF)transfected cells were shown to improve functional outcomes, and increase the proliferation of endothelial cells, suggesting increased angiogenesis ${ }^{[149]}$. These results prompt further study of HIF, especially given HIF's role in inducing the expression of various previously discussed factors, including VEGF, EPO, and HB-EGF. Transplanted NPCs have also been shown to promote endogenous NPC proliferation in the SVZ ${ }^{[150,151]}$, angiogenesis ${ }^{[151]}$, and to release various trophic factors to promote axonal and dendritic plasticity ${ }^{[152]}$. The latter study found that the predominantly released factor was VEGF, which may explain the proliferative and angiogenic effects.

\section{Conclusion}

There is much excitement surrounding the potential for NPCs to promote tissue repair and functional recovery following stroke. Both exogenous and endogenous approaches to cellbased therapy using NPCs have shown promising results in preclinical studies. However, it may be that neither alone will be sufficient for promoting full recovery post-stroke, especially 
when considering the need to apply these strategies in old age where the numbers of NPCs are fewer. Indeed, transition to the clinic will ultimately require rigorous evaluation of not only the activation factors being employed, but also how the exogenous and endogenous approaches can be used together to complement each other, with the end-goal of achieving functional and cognitive recovery.

\section{Abbreviations}

$\mathrm{AAV}$, adeno-associated virus; Ang 1, angiopoietin 1; BDNF, brain derived neurotrophic factor; $\mathrm{BMMC}$, bone marrow mononuclear cells; BMP-7, bone morphogenic protein 7; BrdU, bromodeoxyuridine; CNS, central nervous system; CsA, cyclosporine A; DG, dentate gyrus; EGF, epidermal growth factor; EGFR, epidermal growth factor receptor; EPO, erythropoietin; FGF-2, basic fibroblast growth factor; G-CSF, granulocyte colony-stimulating factor; GDNF, glial cell line-derived neurotrophic factor; GFAP, glial fibrillary acidic protein; $\mathrm{GH}$, growth hormone; HB-EGF, heparin-binding EGF-like growth factor; HIF, hypoxia induction factor; IGF-1, insulinlike growth factor 1; iPSC, induced pluripotent stem cells; $\mathrm{MCAO}$, middle cerebral artery occlusion; MCP-1, monocyte chemoattractant protein 1; MMP, matrix metalloproteinase; MSC, mesenchymal stem cells; NPC, neural precursor cell; PI3K, phosphoinositide-3-kinase; PUMA, p53-upregulated modulator of apoptosis; RMS, rostral migratory stream; SDF-1, stromal cell-derived factor 1; STEPS, Stem Cell Therapies as an Emerging Paradigm in Stroke; SVZ, subventricular zone; TGF$a$, transforming growth factor alpha; t-PA, thrombolytic tissue plasminogen activator; VEGF, vascular endothelial growth factor.

\section{References}

1 Hacke W, Kaste M, Bluhmki E, Brozman M, Dávalos A, Guidetti D, et al. Thrombolysis with alteplase 3 to 4.5 hours after acute ischemic stroke. N Engl J Med 2008; 359: 1317-29.

2 Shobha N, Buchan AM, Hill MD, Canadian alteplase for stroke effectiveness study (CASES). Thrombolysis at 3-4.5 hours after acute ischemic stroke onset - evidence from the canadian alteplase for stroke effectiveness study (CASES) registry. Cerebrovasc Dis 2011; 31: 223-8.

3 Gage FH. Mammalian neural stem cells. Science 2000; 287 : 1433-8.

4 Reynolds BA, Weiss S. Generation of neurons and astrocytes from isolated cells of the adult mammalian central nervous system. Science 1992; 255: 1707-10.

5 Reynolds BA, Weiss S. Clonal and population analyses demonstrate that an EGF-responsive mammalian embryonic CNS precursor is a stem cell. Dev Biol 1996; 175: 1-13.

6 Morshead CM, Reynolds BA, Craig CG, McBurney MW, Staines WA, Morassutti D, et al. Neural stem cells in the adult mammalian forebrain: A relatively quiescent subpopulation of subependymal cells. Neuron 1994; 13: 1071-82.

7 Palmer TD, Ray J, Gage FH. FGF-2-responsive neuronal progenitors reside in proliferative and quiescent regions of the adult rodent brain. Mol Cell Neurosci 1995; 6: 474-86.

8 Chiasson BJ, Tropepe V, Morshead CM, van der Kooy D. Adult mammalian forebrain ependymal and subependymal cells demon- strate proliferative potential, but only subependymal cells have neural stem cell characteristics. J Neurosci 1999; 19: 4462-71.

9 Quiñones-Hinojosa A, Chaichana K. The human subventricular zone: A source of new cells and a potential source of brain tumors. Exp Neurol 2007; 205: 313-24.

10 Morshead CM, Garcia AD, Sofroniew MV, van der Kooy D. The ablation of glial fibrillary acidic protein-positive cells from the adult central nervous system results in the loss of forebrain neural stem cells but not retinal stem cells. Eur J Neurosci 2003; 18: 76-84.

11 Garcia AD, Doan NB, Imura T, Bush TG, Sofroniew MV. GFAP-expressing progenitors are the principal source of constitutive neurogenesis in adult mouse forebrain. Nat Neurosci 2004; 7: 1233-41.

12 Doetsch F, Caillé I, Lim DA, García-Verdugo JM, Alvarez-Buylla A. Subventricular zone astrocytes are neural stem cells in the adult mammalian brain. Cell 1999; 97: 703-16.

13 Lois C, Alvarez-Buylla A. Long-distance neuronal migration in the adult mammalian brain. Science 1994; 264: 1145-8.

14 Carleton A, Petreanu LT, Lansford R, Alvarez-Buylla A, Lledo PM. Becoming a new neuron in the adult olfactory bulb. Nat Neurosci 2003; 6: 507-18.

15 Lledo PM. Adult neurogenesis in the olfactory bulb. In: Gage FH, Kempermann G, Song H, editors. Adult Neurogenesis. Cold Spring Harbor (NY): Cold Spring Harbor Lab Press; 2008. p 425-43.

16 Sanai N, Tramontin AD, Quiñones-Hinojosa A, Barbaro NM, Gupta $\mathrm{N}$, Kunwar $\mathrm{S}$, et al. Unique astrocyte ribbon in adult human brain contains neural stem cells but lacks chain migration. Nature 2004; 427: $740-4$.

17 van den Berge SA, Middeldorp J, Zhang CE, Curtis MA, Leonard BW, Mastroeni $D$, et al. Longterm quiescent cells in the aged human subventricular neurogenic system specifically express GFAP- $\delta$. Aging Cell 2010; 9: 313-26.

18 Curtis MA, Kam M, Nannmark U, Anderson MF, Axell MZ, Wikkelso C, et al. Human neuroblasts migrate to the olfactory bulb via a lateral ventricular extension. Science 2007; 315: 1243-9.

19 Wang C, Liu F, Liu YY, Zhao CH, You Y, Wang L, et al. Identification and characterization of neuroblasts in the subventricular zone and rostral migratory stream of the adult human brain. Cell Res 2011; 21: 1534-50.

20 Cameron HA, Wooley CS, McEwen BS, Gould E. Differentiation of newly born neurons and glia in the debate gyrus of the adult rat. Neuroscience 1993; 56: 337-44.

21 Kuhn GH, Dickinson-Anson H, Gage FH. Neurogenesis in the dentate gyrus of the adult rat: age-related decrease of neuronal progenitor proliferation. J Neurosci 1996; 16: 2027-33.

22 Seri B, Garcia-Verdugo JM, McEwen BS, Alvarez-Buylla A. Astrocytes give rise to new neurons in the adult mammalian hippocampus. J Neurosci 2001; 21: 7153-60.

23 Kempermann G, Jessberger S, Steiner B, Kronenberg G. Milestones of neuronal development in the adult hippocampus. Trends Neurosci 2004; 27: 447-52.

24 Kempermann G, Song H, Gage FH. Neurogenesis in the adult hippocampus. In: Gage FH, Kempermann G, Song H, editors. Adult neurogenesis. Cold Spring Harbor (NY): Cold Spring Harbor Lab Press; 2008. p 159-70.

25 Babu H, Cheung G, Kettenmann H, Palmer TD, Kempermann G. Enriched monolayer precursor cell cultures from micro-dissected adult mouse dentate gyrus yield functional granule cell-like neurons. PLoS One 2007; 2: e388. doi: 10.1371/journal.pone.0000388.

26 Clarke L, van der Kooy D. The adult mouse dentate gyrus contains populations of committed progenitor cells that are distinct from subependymal zone neural stem cells. Stem Cells 2011; 29: 1448- 
58.

27 Eriksson PS, Perfilieva E, Björk-Eriksson T, Alborn AM, Nordborg C, Peterson DA, et al. Neurogenesis in the adult human hippocampus. Nat Med 1998; 4: 1313-7.

28 Manganas LN, Zhang X, Li Y, Hazel RD, Smith SD, Wagshul ME, et al. Magnetic resonance spectroscopy identifies neural progenitor cells in the live human brain. Science 2007; 318: 980-5.

29 Blum S, Luchsinger JA, Manly JJ, Schupf N, Stern Y, Brown TR, et al. Memory after silent stroke: Hippocampus and infarcts both matter. Neurology 2012; 78: 38-46.

30 Liu J, Solway K, Messing RO, Sharp FR. Increased neurogenesis in the dentate gyrus after transient global ischemia in gerbils. J Neurosci 1998; 18: 7768-78.

31 Lindvall O, Kokaia Z. Neurogenesis following stroke affecting the adult brain. In: Gage FH, Kempermann G, Song H, editors. Adult Neurogenesis. Cold Spring Harbor (NY): Cold Spring Harbor Lab Press; 2008. p 549-70.

32 Lindvall 0 , Kokaia Z. Neurogenesis from endogenous neural stem cells after stroke: A future therapeutic target to promote functional restoration? In: Seki Y, Sawamoto K, Parent JM, Alvarez-Buylla M, editors. Neurogenesis in the Adult Brain II: Clinical Implications. New York: Springer; 2011. p 133-48.

33 Watson BD, Dietrich WD, Busto R, Wachtel MS, Ginsberg MD. Induction of reproducible brain infarction by photochemically initiated thrombosis. Ann Neurol 1985; 17: 497-504.

34 Schäbitz WR, Steigleder T, Cooper-Kuhn CM, Schwab S, Sommer C, Schneider A, et al. Intravenous brain-derived neurotrophic factor enhances poststroke sensorimotor recovery and stimulates neurogenesis. Stroke 2007; 38: 2165-72.

35 Gonzalez C, Kolb B. A comparison of different models of stroke on behaviour and brain morphology. Eur J Neurosci 2003; 18: 195062.

36 Windle V, Szymanska A, Granter-Button S, White C, Buist R, Peeling $J$, et al. An analysis of four different methods of producing focal cerebral ischemia with endothelin-1 in the rat. Exp Neurol 2006; 201: 324-34.

37 Polezhaev LV, Alexandrova MA, Girman SV. Normalization of dystrophic brain cortex neurons after hypoxia and transplantation of embryonic nervous tissue in rats. J Hirnforschung 1986; 27: 501-13.

38 Aihara N, Mizukawa K, Koide K, Mabe H, Nishino H. Striatal grafts in infarct striatopallidum increase GABA release, reorganize $\mathrm{GABA}_{\mathrm{A}}$ receptor and improve water-maze learning in the rat. Brain Res Bull 1994; 33: 483-8.

39 Savitz SI, Dinsmore J, Wu J, Henderson GV, Stieg P, Caplan LR. Neurotransplantation of fetal porcine cells in patients with basal ganglia infarcts: a preliminary safety and feasibility study. Cerebrovasc Dis 2005; 20: 101-7.

40 Kondziolka D, Steinberg GK, Wechsler L, Meltzer CC, Elder E, Gebel J, et al. Neurotransplantation for patients with subcortical motor stroke: a phase 2 randomized trial. J Neurosurg 2005; 103: 38-45.

41 Bang OY, Lee JS, Lee PH, Lee G. Autologous mesenchymal stem cell transplantation in stroke patients. Ann Neurol 2005; 57: 874-82.

42 Lee JS, Hong JM, Moon GJ, Lee PH, Ahn YH, Bang OY, et al. A longterm follow-up study of intravenous autologous mesenchymal stem cell transplantation in patients with ischemic stroke. Stem Cells 2010; 28: 1099-106.

43 Burns TC, Steinberg GK. Stem cells and stroke: opportunities, challenges and strategies. Expert Opin Biol Ther 2011; 11: 447-61.

44 Ishibashi S, Sakaguchi M, Kuroiwa T, Yamasaki M, Kanemura Y, Shizuko I, et al. Human neural stem/progenitor cells, expanded in long-term neurosphere culture, promote functional recovery after focal ischemia in mongolian gerbils. J Neurosci Res 2004; 78: 21523.

45 Darsalia V, Kallur T, Kokaia Z. Survival, migration and neuronal differentiation of human fetal striatal and cortical neural stem cells grafted in stroke-damaged rat striatum. Eur J Neurosci 2007; 26: 605-14.

46 Bühnemann C, Scholz A, Bernreuther C, Malik CY, Braun H, Schachner $\mathrm{M}$, et al. Neuronal differentiation of transplanted embryonic stem cell-derived precursors in stroke lesions of adult rats. Brain 2006; 129: 3238-48.

47 Daadi MM, Maag AL, Steinberg GK. Adherent self-renewable human embryonic stem cell-derived neural stem cell line: functional engraftment in experimental stroke model. PLoS One 2008; 3 : e1644. doi:10.1371/journal.pone.0001644.

48 ReNeuron Limited. Pilot Investigation of Stem Cells in Stroke (PISCES). In: ClinicalTrials.gov [Internet]. Bethesda (MD): National Library of Medicine (US). 2000- [cited 2012 Apr 11]. Available from http://clinicaltrials.gov/ct2/show/NCT01151124 NLM identifier: NCT01151124.

49 Jensen MB, Yan H, Krishnaney-Davison R, Al Sawaf A, Zhang SC. Survival and differentiation of transplanted neural stem cells derived from human induced pluripotent stem cells in a rat stroke model. J Stroke Cerebrovasc Dis 2011. Doi: 10.1016/j.jstrokecerebrovasdis.2 011.09.008.

50 Zhang ZG, Jiang Q, Zhang R, Zhang L, Wang L, Zhang L, et al. Magnetic resonance imaging and neurosphere therapy of stroke in rat. Ann Neurol 2003; 53: 259-63.

51 Hicks AU, Hewlett K, Windle V, Chernenko G, Ploughman M, Jolkkonen J, et al. Enriched environment enhances transplanted subventricular zone stem cell migration and functional recovery after stroke. Neuroscience 2007; 146: 31-40.

52 Takahashi K, Yasuhara T, Shingo T, Muraoka K, Kameda M, Takeuchi A, et al. Embryonic neural stem cells transplanted in middle cerebral artery occlusion model of rats demonstrated potent therapeutic effects, compared to adult neural stem cells. Brain Res 2008; 1234 : 172-82.

53 Jin K, Sun Y, Xie L, Mao XO, Childs J, Peel A, et al. Comparison of ischemia-directed migration of neural precursor cells after intrastriatal, intraventricular, or intravenous transplantation in the rat. Neurobiol Dis 2005; 18: 366-74.

54 Shen CC, Lin CH, Yang YC, Chiao MT, Cheng WY, Ko JL. Intravenous implanted neural stem cells migrate to injury site, reduce infarct volume, and improve behavior after cerebral ischemia. Curr Neurovasc Res 2010; 7: 167-79.

55 Minnerup J, Kim JB, Schmidt A, Diederich K, Bauer H, Schilling M, et al. Effects of neural progenitor cells on sensorimotor recovery and endogenous repair mechanisms after photothrombotic stroke. Stroke 2011; 42: 1757-63.

56 Janowski M, Walczak P, Date I. Intravenous route of cell delivery for treatment of neurological disorders: a meta-analysis of preclinical results. Stem Cells Dev 2010; 19: 5-16.

57 Arvidsson A, Collin T, Kirik D, Kokaia Z, Lindvall O. Neuronal replacement from endogenous precursors in the adult brain after stroke. Nat Med 2002; 8: 963-70.

58 Parent JM, Vexler ZS, Gong C, Derugin N, Ferriero DM. Rat forebrain neurogenesis and striatal neuron replacement after focal stroke. Ann Neurol 2002; 52: 802-13.

59 Thored P, Arvidsson A, Cacci E, Ahlenius H, Kallur T, Darsalia V. Persistent production of neurons from adult brain stem cells during recovery after stroke. Stem Cells 2006; 24: 739-47.

60 Yamashita T, Ninomiya M, Hernández Acosta P, García-Verdugo JM, 
Sunabori T, Sakaguchi M, et al. Subventricular zone-derived neuroblasts migrate and differentiate into mature neurons in the poststroke adult striatum. J Neurosci 2006; 26: 6627-36.

61 Hou SW, Wang YQ, Xu M, Shen DH, Wang JJ, Huang F, et al. Functional integration of newly generated neurons into striatum after cerebral ischemia in the adult rat brain. Stroke 2008; 39: 2837-44.

62 Jin K, Wang X, Xie L, Mao XO, Zhu W, Wang Y, et al. Evidence for stroke-induced neurogenesis in the human brain. Proc Natl Acad Sci U S A 2006; 103: 13198-202.

63 Martí-Fàbregas J, Romaguera-Ros M, Gómez-Pinedo U, MartínezRamírez S, Jiménez-Xarrié E, Marín R, et al. Proliferation in the human ipsilateral subventricular zone after ischemic stroke. Neurology 2010; 74: 357-65.

64 Kee NJ, Preston E, Woitowicz JM. Enhanced neurogenesis after transient global ischemia in the dentate gyrus of the rat. Exp Brain Res 2001; 136: 313-20.

65 Kempermann G. Adult neurogenesis 2: Stem cells and neuronal development in the adult brain. 2nd ed. Toronto: Oxford University Press; 2011.

66 Zhang R, Zhang Z, Wang L, Wang Y, Gousev A, Zhang L, et al. Activated neural stem cells contribute to stroke induced neurogenesis and neuroblast migration toward the infarct boundary in rats. J Cereb Blood Flow Metab 2004; 24: 441-8.

67 Zhang RL, LeTourneau Y, Gregg SR, Wang Y, Toh Y, Robin AM, et al. Neuroblast division during migration toward the ischemic striatum: a study of dynamic migratory and proliferative characteristics of neuroblasts from the subventricular zone. J Neurosci 2007; 27: 3157-62.

68 Morshead CM, Craig CG, van der Kooy D. In vivo clonal analysis of endogenous neural stem cell proliferation in the adult mammalian forebrain. Development 1998; 125: 2251-61.

69 Morshead CM, van der Kooy D. Postmitotic death is the fate of constitutively proliferating cells in the subependymal layer of the adult mouse brain. J Neurosci 1992; 12: 249-56.

70 Craig CG, Tropepe V, Morshead CM, Reynolds BA, Weiss S, van der Kooy D. In vivo growth factor expansion of endogenous subependymal neural precursor cell populations in the adult mouse brain. J Neurosci 1996; 16: 2649-58.

71 Teramoto T, Qiu J, Plumier JC, Moskowitz MA. EGF amplifies the replacement of parvalbumin-expressing striatal interneurons after ischemia. J Clin Invest 2003; 111: 1125-32.

72 Kolb B, Morshead C, Gonzalez C, Kim M, Gregg C, Shingo T, et al. Growth factor-stimulated generation of new cortical tissue and functional recovery after stroke damage to the motor cortex of rats. J Cereb Blood Flow Metab 2007; 27: 983-97.

73 Alagappan D, Lazzarino DA, Felling RJ, Balan M, Kotenko SV, Levison SW. Brain injury expands the numbers of neural stem cells and progenitors in the SVZ by enhancing their responsiveness to EGF. ASN Neuro 2009; 1: e00009. doi: 10.1042/AN20090002.

74 Jin K, Sun Y, Xie L, Childs J, Mao X. Post-ischemic administration of heparin-binding epidermal growth factor-like growth factor (HB-EGF) reduces infarct size and modifies neurogenesis after focal cerebral ischemia. Cereb Blood Flow Metab 2004; 24: 399-408.

75 Jin K, Zhu Y, Sun Y, Mao XO, Xie L, Greenberg DA. Vascular endothelial growth factor (VEGF) stimulates neurogenesis in vitro and in vivo. Proc Natl Acad Sci U S A 2002; 99: 11946-50.

76 Wittko IM, Schanzer A, Kuzmichev A, Schneider FT, Shibuya M, Raab $\mathrm{S}$, et al. VEGFR-1 regulates adult olfactory bulb neurogenesis and migration of neural progenitors in the rostral migratory stream in vivo. J Neurosci 2009; 29: 8704-14.

77 Shin YJ, Choi JS, Choi JY, Cha JH, Chun MH, Lee MY. Enhanced expression of vascular endothelial growth factor receptor-3 in the subventricular zone of stroke-lesioned rats. Neurosci Lett 2010; 469: 194-8.

78 Kobayashi T, Ahlenius H, Thored P, Kobayashi R, Kokaia Z, Lindvall O. Intracerebral infusion of glial cell line-derived neurotrophic factor promotes striatal neurogenesis after stroke in adult rats. Stroke 2006; 37: 2361-7.

79 Schneider A, Kruger C, Steigleder T, Weber D, Pitzer C, Laage R, et al. The hematopoietic factor G-CSF is a neuronal ligand that counteracts programmed cell death and drives neurogenesis. J Clin Invest 2005; 115: 2083-98.

80 Popa-Wagner A, Stöcker K, Balseanu AT, Rogalewski A, Diederich K, Minnerup J, et al. Effects of granulocyte-colony stimulating factor after stroke in aged rats. Stroke 2010; 41: 1027-31.

81 Leker RR, Soldner F, Velasco I, Gavin DK, Androutsellis-Theotokis A, McKay RD. Long-lasting regeneration after ischemia in the cerebral cortex. Stroke 2007; 38: 153-61.

82 Dempsey RJ, Sailor KA, Bowen KK, Tureyen K, Vemuganti R. Strokeinduced progenitor cell proliferation in adult spontaneously hypertensive rat brain: effect of exogenous IGF-1 and GDNF. J Neurochem 2003; 87: 586-97.

83 Zhu W, Fan Y, Hao Q, Shen F, Hashimoto T, Yang GY, et al. Postischemic IGF-1 gene transfer promotes neurovascular regeneration after experimental stroke. J Cereb Blood Flow Metab 2009; 29: 1528-37.

84 Chou J, Harvey BK, Chang CF, Shen H, Morales M, Wang Y. Neuroregenerative effects of BMP7 after stroke in rats. J Neurol Sci 2006; 240: 21-9.

85 Guerra-Crespo M, Gleason D, Sistos A, Toosky T, Solaroglu I, Zhang $\mathrm{JH}$, et al. Transforming growth factor-alpha induces neurogenesis and behavioral improvement in a chronic stroke model. Neuroscience 2009; 160: 470-83.

86 Tsai PT, Ohab JJ, Kertesz N, Groszer M, Matter C, Gao J, et al. A critical role of erythropoietin receptor in neurogenesis and poststroke recovery. J Neurosci 2006; 26: 1269-74.

87 Wang L, Zhang Z, Wang Y, Zhang R, Chopp M. Treatment of stroke with erythropoietin enhances neurogenesis and angiogenesis and improves neurological function in rats. Stroke 2004; 35: 1732-7.

88 Yuen CM, Leu S, Lee FY, Yen CH, Lin YC, Chua S, et al. Erythropoietin markedly attenuates brain infarct size and improves neurological function in the rat. J Invest Med 2010; 58: 893-904.

89 Wang Y, Cooke MJ, Morshead CM, Shoichet MS. Hydrogel delivery of erythropoietin to the brain for endogenous stem cell stimulation after stroke injury. Biomaterials 2012; 33: 2681-92.

90 McLenachan S, Luma MG, Waters MJ, Turnley AM. Growth hormone promotes proliferation of adult neurosphere cultures. Growth Hormone IGF Res 2009; 19: 212-18.

91 Blackmore DG, Reynolds BA, Golmohammadi MG, Large B, Aguilar RM, Haro L, et al. Growth hormone responsive neural precursor cells reside within the adult mammalian brain. Sci Reports 2012; 2: 250. doi:10.1038/.srep00250

92 Kilic E, Kilic U, Bacigaluppi M, Guo Z, Abdallah NB, Wolfer DP, et al. Delayed melatonin administration promotes neuronal survival, neurogenesis and motor recovery, and attenuates hyperactivity and anxiety after mild focal cerebral ischemia in mice. J Pineal Res 2008; 45: 142-8.

93 Chern CM, Liao JF, Wang YH, Shen YC. Melatonin ameliorates neural function by promoting endogenous neurogenesis through the MT2 melatonin receptor in ischemic-stroke mice. Free Radic Biol Med 2012; 52: 1634-47.

94 Li J, Siegel M, Yuan M, Zeng Z, Finnucan L, Persky R, et al. Estrogen enhances neurogenesis and behavioral recovery after stroke. J 
Cereb Blood Flow Metab 2011; 31: 413-25.

95 Sinor AD, Lillien L. Akt-1 expression level regulates CNS precursors. J Neurosci 2004; 24: 8531-41.

96 Cantley LC. The phosphoinositide 3-kinase pathway. Science 2002; 296: 1655-57.

97 Solaroglu I, Tsubokawa T, Cahill J, Zhang JH. Anti-apoptotic effect of granulocyte-colony stimulating factor after focal cerebral ischemia in the rat. Neuroscience 2006; 143: 965-74.

98 Kalluri HSG, Vemuganti R, Dempsey RJ. Mechanism of insulin-like growth factor I-mediated proliferation of adult neural progenitor cells: role of Akt. Eur J Neurosci 2007; 25: 1041-8.

99 Meletis K, Wirta V, Hede SM, Nistér M, Lundeberg J, Frisén J. p53 suppresses the self-renewal of adult neural stem cells. Development 2006; 133: 363-9.

100 Luo Y, Kuo C, Shen H, Chou J. Delayed treatment with a p53 inhibitor enhances recovery in stroke brain. Ann Neurol 2009; 65: 520-30.

101 Leker RR, Aharonowiz M, Greig NH, Ovadia H. The role of p53induced apoptosis in cerebral ischemia: effects of the p53 inhibitor pifithrin $\alpha$. Exp Neurol 2004; 187: 478-86.

102 Niizuma K, Endo H, Nito C, Myer DJ, Chan PH. Potential role of PUMA in delayed death of hippocampal CA1 neurons after transient global cerebral ischemia. Stroke 2009; 40: 618-25.

103 Hunt J, Cheng A, Hoyles A, Jervis E, Morshead CM. Cyclosporin A has direct effects on adult neural precursor cells. J Neurosci 2010; 30: 2888-96.

104 Erlandsson A, Lin CHA, Yu F, Morshead CM. Immunosuppression promotes endogenous neural stem and progenitor cell migration and tissue regeneration after ischemic injury. Exp Neurol 2011; 230 : 48-57.

105 Piccin D, Morshead CM. Wnt signaling regulates symmetry of division in adult neural stem cells. Stem Cells 2011; 29: 528-38.

106 Ables JL, Breunig JJ, Eisch AJ, Rakic P. Not(ch) just development: Notch signalling in the adult brain. Nat Rev Neurosci 2011; 12 : 269-83.

107 Wang L, Chopp M, Zhang RL, Zhang L, Letourneau Y, Feng YF, et al. The Notch pathway mediates expansion of a progenitor pool and neuronal differentiation in adult neural progenitor cells after stroke. Neuroscience 2009; 158: 1356-63.

108 Wang X, Mao X, Xie L, Greenberg DA, Jin K. Involvement of Notch1 signaling in neurogenesis in the subventricular zone of normal and ischemic rat brain in vivo. J Cereb Blood Flow Metab 2009; 29: 1644-54.

109 Androutsellis-Theotokis A, Leker RR, Soldner F, Hoeppner DJ, Ravin R, Poser SW, et al. Notch signalling regulates stem cell numbers in vitro and in vivo. Nature 2006; 442: 823-6.

110 Ohab JJ, Fleming S, Blesch A, Carmichael ST. A neurovascular niche for neurogenesis after stroke. J Neurosci 2006; 26: 13007-16.

111 Yan YP, Sailor KA, Lang BT, Park SW, Vemuganti R, Dempsey RJ. Monocyte chemoattractant protein-1 plays a critical role in neuroblast migration after focal cerebral ischemia. J Cereb Blood Flow Metab 2007; 27: 1213-24.

112 Yan YP, Lang BT, Vemuganti R, Dempsey RJ. Osteopontin is a mediator of the lateral migration of neuroblasts from the subventricular zone after focal cerebral ischemia. Neurochem Int 2009; 55: 826-32.

113 Wang Z, Andrade N, Torp M, Wattananit S, Arvidsson A, Kokaia Z, et al. Meteorin is a chemokinetic factor in neuroblast migration and promotes stroke-induced striatal neurogenesis. J Cereb Blood Flow Metab 2012; 32: 387-98.

114 Shinjyo N, Ståhlberg A, Dragunow M, Pekny M, Pekna M. Complement-derived anaphylatoxin $\mathrm{C} 3$ a regulates in vitro differentiation and migration of neural progenitor cells. Stem Cells 2009; 27: 2824-32.

115 Liu XS, Zhang ZG, Zhang RL, Gregg SR, Wang L, Yier T, et al. Chemokine ligand 2 (CCL2) induces migration and differentiation of subventricular zone cells after stroke. J Neurosci Res 2007; 85: 2120-5.

116 Dimitrijevic OB, Stamatovic SM, Keep RF, Andjelkovic AV. Absence of the chemokine receptor CCR2 protects against cerebral ischemia/ reperfusion injury in mice. Stroke 2007; 38: 1345-53.

117 Schilling M, Strecker JK, Ringelstein EB, Schäbitz WR, Kiefer R. The role of $\mathrm{CC}$ chemokine receptor 2 on microglia activation and bloodborne cell recruitment after transient focal cerebral ischemia in mice. Brain Res 2009; 1289: 79-84.

118 Stumm R, Höllt V. CXC chemokine receptor 4 regulates neuronal migration and axonal pathfinding in the developing nervous system: implications for neuronal regeneration in the adult brain. $\mathrm{J} \mathrm{Mol}$ Endocrinol 2007; 38: 377-82.

119 Van Lint P, Libert C. Chemokine and cytokine processing by matrix metalloproteinases and its effect on leukocyte migration and inflammation. J Leukoc Biol 2007; 82: 1375-81.

120 Barkho BZ, Munoz AE, Li X, Li L, Cunningham LA, Zhao X. Endogenous matrix metalloproteinase (MMP)-3 and MMP-9 promote the differentiation and migration of adult neural progenitor cells in response to chemokines. Stem Cells 2008; 26: 3139-49.

121 Lee SR, Kim HY, Rogowska J, Zhao BQ, Bhide P, Parent JM, et al. Involvement of matrix metalloproteinase in neuroblast cell migration from the subventricular zone after stroke. J Neurosci 2006; 26: 3491-5.

122 Kalluri HSG, Dempsey RJ. Growth factors, stem cells, and stroke. Neurosurg focus 2008; 24: E14. doi: 10.3171/FOC/2008/24/3-4/ E13.

123 Wang L, Zhang ZG, Zhang RL, Gregg SR, Hozeska-Solgot A, LeTourneau Y, et al. Matrix metalloproteinase 2 (MMP2) and MMP9 secreted by erythropoietin-activated endothelial cells promote neural progenitor cell migration. J Neurosci 2006; 26: 5996-6003.

124 Kang SS, Kook JH, Hwang S, Park SH, Nam SC, Kim JK. Inhibition of matrix metalloproteinase-9 attenuated neural progenitor cell migration after photothrombotic ischemia. Brain Res 2008; 1228: 20-6.

125 Babona-Pilipos R, Droujinine IA, Popovic MR, Morshead CM. Adult subependymal neural precursors, but not differentiated cells, undergo rapid cathodal migration in the presence of direct current electric fields. PLoS One 2011; 6: e23808. doi:10.1371/journal. pone.0023808.

126 McCaig CD, Rajnicek AM, Song B, Zhao M. Controlling cell behavior electrically: current views and future potential. Physiol Rev 2005; 85: 943-78.

127 Sugiura S, Kitagawa K, Tanaka S, Todo K, Omura-Matsuoka E, Sasaki $\mathrm{T}$, et al. Adenovirus-mediated gene transfer of heparin-binding epidermal growth factor-like growth factor enhances neurogenesis and angiogenesis after focal cerebral ischemia in rats. Stroke 2005; 36: 859-64.

128 Wang YQ, Cui HR, Yang SZ, Sun HP, Qiu MH, Feng XY, et al. VEGF enhance cortical newborn neurons and their neurite development in adult rat brain after cerebral ischemia. Neurochem Int 2009; 55: 629-36.

129 Lindvall O, Kokaia Z. Stem cell research in stroke: How far from the clinic? Stroke 2011; 42: 2369-75.

130 Zhang ZG, Chopp M. Neurorestorative therapies for stroke: underlying mechanisms and translation to the clinic. Lancet Neurol 2009; 8: 491-500.

131 Teng H, Zhang ZG, Wang L, Zhang RL, Zhang L, Morris D, et al. Coupling of angiogenesis and neurogenesis in cultured endothelial cells and neural progenitor cells after stroke. J Cereb Blood Flow 
Metab 2008; 28: 764-71.

132 Thored P, Wood J, Arvidsson A, Cammenga J, Kokaia Z, Lindvall 0. Long-term neuroblast migration along blood vessels in an area with transient angiogenesis and increased vascularization after stroke. Stroke 2007; 38: 3032-9.

133 Kojima T, Hirota Y, Ema M, Takahashi S, Miyoshi I, Okano H, et al. Subventricular zone-derived neural progenitor cells migrate along a blood vessel scaffold toward the post-stroke striatum. Stem Cells 2010; 28: 545-54.

134 Li WL, Fraser JL, Yu SP, Zhu J, Jiang YJ, Wei L. The role of VEGF/ VEGFR2 signaling in peripheral stimulation-induced cerebral neurovascular regeneration after ischemic stroke in mice. Exp Brain Res 2011; 214: 503-13.

135 Cooke MJ, Wang Y, Morshead CM, Shoichet MS. Biomaterials controlled epi-cortical delivery of epidermal growth factor for the stimulation of endogenous neural stem cell proliferation in strokeinjured brain. Biomaterials 2011; 32: 5688-97.

136 Darsalia V, Heldmann U, Lindvall 0, Kokaia Z. Stroke-induced neurogenesis in aged brain. Stroke 2005; 36: 1790-5.

137 Walter J, Keiner S, Witte OW, Redecker C. Differential stroke-induced proliferative response of distinct precursor cell subpopulations in the young and aged dentate gyrus. Neurosci 2010; 169: 1279-86.

138 Gao P, Shen F, Gabriel RA, Law D, Yang E, Yang GY, et al. Attenuation of brain response to vascular endothelial growth factor-mediated angiogenesis and neurogenesis in aged mice. Stroke 2009; 40: 3596-600.

139 Won SJ, Xie L, Kim SH, Tang H, Wang Y, Mao X, et al. Influence of age on the response to fibroblast growth factor-2 treatment in a rat model of stroke. Brain Res 2006; 1123: 237-44.

140 Buga AM, Sascau M, Pisoschi C, Herndon JG, Kessler C, Popa-Wagner A. The genomic response of the ipsilateral and contralateral cortex to stroke in aged rats. J Cell Mol Med 2008; 12: 2731-53.

141 Fisher M, Feuerstein G, Howells DW, Hurn PD, Kent TA, Savitz SI, et al. Update of the stroke therapy academic industry roundtable preclinical recommendations. Stroke 2009; 40: 2244-50.

142 Savitz SI, Chopp M, Deans R, Carmichael ST, Phinney D, Wechsler L. Stem cell therapy as an emerging paradigm for stroke (STEPS) II. Stroke 2011; 41: 825-9.

143 Cook DJ, Tymianski M. Nonhuman primate models of stroke for translational neuroprotection research. Neurotherapeutics 2012; 9: 371-9.

144 Masuda T, Isobe Y, Aihara N, Furuyama F, Misumi S, Kim TS, et al. Increase in neurogenesis and neuroblast migration after a small intracerebral hemorrhage in rats. Neurosci Lett 2007; 425: 114-9.

145 Shen J, Xie L, Mao X, Zhou Y, Zhan R, Greenberg DA, et al. Neurogenesis after primary intracerebral hemorrhage in adult human brain. J Cereb Blood Flow Metab 2008; 28: 1460-8.

146 Lee HJ, Lim IJ, Lee MC, Kim SU. Human neural stem cells genetically modified to overexpress brain-derived neurotrophic factor promote functional recovery and neuroprotection in a mouse stroke model. J Neurosci Res 2010; 88: 3282-94.

147 Zhu JM, Zhao YY, Chen SD, Zhang WH, Lou L, Jin X. Functional recovery after transplantation of neural stem cells modified by brainderived neurotrophic factor in rats with cerebral ischaemia. J Int Med Res 2011; 39: 488-98.

148 Chen B, Gao XQ, Yang CX, Tan SK, Sun ZL, Yan NH, et al. Neuroprotective effect of grafting GDNF gene-modified neural stem cells on cerebral ischemia in rats. Brain Res 2009; 1284: 1-11.

149 Wu W, Chen X, Hu C, Li J, Yu Z, Cai W. Transplantation of neural stem cells expressing hypoxia-inducible factor-1alpha (HIF-1alpha) improves behavioral recovery in a rat stroke model. J Clin Neurosci 2010; 17: 92-5.

150 Jin K, Xie L, Mao X, Greenberg MB, Moore A, Peng B, et al. Effect of human neural precursor cell transplantation on endogenous neurogenesis after focal cerebral ischemia in the rat. Brain Res 2011; 1374: 56-62.

151 Zhang P, Li J, Liu Y, Chen X, Lu H, Kang Q, et al. Human embryonic neural stem cell transplantation increases subventricular zone cell proliferation and promotes peri-infarct angiogenesis after focal cerebral ischemia. Neuropathology 2011; 31: 384-91.

152 Andres RH, Horie N, Slikker W, Keren-Gill H, Zhan K, Sun G, et al. Human neural stem cells enhance structural plasticity and axonal transport in the ischaemic brain. Brain 2011; 134: 1777-89.

153 Türeyen K, Vemuganti R, Bowen KK, Sailor KA, Dempsey RJ. EGF and FGF-2 infusion increases post-ischemic neural progenitor cell proliferation in the adult rat brain. Neurosurgery 2005; 57: 125463.

154 Sun Y, Jin K, Xie L, Childs J, Mao XO, Logvinova A, et al. VEGFinduced neuroprotection, neurogenesis, and angiogenesis after focal cerebral ischemia. J Clin Invest 2003; 111: 1843-51.

155 Zhu W, Fan Y, Frenzel T, Gasmi M, Bartus RT, Young WL, et al. Insulin growth factor-1 gene transfer enhances neurovascular remodeling and improves long-term stroke outcome in mice. Stroke 2008; 39: 1254-61.

156 Liu SP, Lee SD, Lee HT, Liu DD, Wang HJ, Liu RS, et al. Granulocyte colony-stimulating factor activating HIF-1alpha acts synergistically with erythropoietin to promote tissue plasticity. PloS One 2010; 5: e10093. doi:10.1371/journal.pone.0010093.

157 Plane JM, Whitney JT, Schallert T, Parent JM. Retinoic acid and environmental enrichment alter subventricular zone and striatal neurogenesis after stroke. Exp Neurol 2008; 214: 125-34. 